\title{
Gender Differences in Perceived Stress Among Economics Education Undergraduate Students in South-East, Nigeria
}

\author{
Sylvester N. Ogbueghu ${ }^{1}$, Patricia Nwamaka Aroh ${ }^{1}$, Robert Augustine Igwe ${ }^{2}$, Jingak Emmanuel Dauda ${ }^{3}$, \\ Daniel M. Eze ${ }^{1}$, Ifeoma Euphemia Opara ${ }^{4}$, Bartholomew C. Nwefuru ${ }^{5} \&$ Njideka Dorathy Eneogu ${ }^{1}$ \\ ${ }^{1}$ Department of Social Science Education, University of Nigeria, Nsukka, Enugu State, Nigeria \\ ${ }^{2}$ Department of Social Science Education, University of Calabar, Calabar, Cross River State, Nigeria \\ ${ }^{3}$ Department of Business Education, Federal College of Education, Pankshin, Plateau State, Nigeria \\ ${ }^{4}$ Department of Economics, FCT College of Education, Zuba, Abuja, Nigeria \\ ${ }^{5}$ Department of Educational Foundations, University of Nigeria, Nsukka, Enugu State, Nigeria \\ Correspondence: Patricia N. Aroh, Department of Social Science Education, University of Nigeria, Nsukka, \\ Enugu State, Nigeria. E-mail: nwamaka.aroh@unn.edu.ng
}

Received: August 18, 2019 Accepted: October 30, 2019 Online Published: November 21, 2019

doi:10.5539/gjhs.v11n14p46 URL: https://doi.org/10.5539/gjhs.v11n14p46

\begin{abstract}
The study objective was to examine gender differences in perceived stress among Economics Education students in federal universities in South-East Nigeria. A cross-sectional survey was adopted which consists of 135 Economics Education undergraduate students. Data collection was done using the Perceived Stress Questionnaire (PSQ). Cronbach alpha reliability of the PSQ was 0.83 . Data collection was done through direct delivery of the questionnaire. Data were analyzed using mean, standard deviation and t-test. Results showed that there is no significant mean difference in perceived stress among male and female Economics education students in universities in South-East Nigeria. Economics Education specialists are urged to implement gender-inclusive teaching interventions to help Economics Education undergraduate students to manage perceived stress.
\end{abstract}

Keywords: economics education, gender, perceived stress, undergraduate students, Federal Universities, South-East, Nigeria

\section{Introduction}

Economics informs us about the ways through which limited resources are shared, the standardization of policies, and offers a superior idea of how the best decision can be made (Finkelstein, 2011). Economics is not limited to policies structuring but also addresses the issue of population and crime, welfare and reduction of educational inequality among others (Hall, 2013). The discipline offers its learners strong knowledge of economic strategies for eliminating human problems. Economics Education, on the other hand, according to Yusuf (2012) is the discipline that concentrates on the current state of and efforts to improve Economics curriculum, materials and conventional techniques employed in the teaching and learning of Economics. Becker (2001) stated that Economics Education is a process, science and product. According to the author, Economics Education as a process involves a time phase of impacting the necessary skills and values on the learners and circulating of valuable Economics information to learners in order for them to improve their standard of living by engaging in admirable businesses. As a science, it implies the body of organized knowledge which is subjected to a scientific test. On the other hand, as a product, it involves the installation of marketable values on the learners which are desirable by employers of labour in the society. According to the National Open University (NOUN) (2006), Economics Education focuses on the effective application of teaching strategies in improving the understanding of Economics and to facilitate basic ideas of students to make them relevant in planning and evaluating policies for societal growth and development. Economics Education is an educational discipline with the target of graduating grounded Economics teachers who will produce learners with better understanding of how policymakers can influence the state economy. Economics Education students are trained to be professional career models in structuring and analyzing policies, making rightful economic decisions; they are trained to be caring, accommodative and tolerant minded while teaching students and affecting lives of the public. Economics Education plays an essential role of equipping individuals with measures, techniques or strategies at which 
Economics principles can be conveyed for rapid growth and development. However, students including those in Economics Education discipline may be influenced or affected by stress because of course-load in their choosing discipline.

Stress often affects people irrespective of their gender. D'Arcy (2007) defines stress as the means through which individual body respond to a task and get ready to adjust in tight area of life. Topper (2007) sees stress as meaning that people attach to demands of their environment (stressors) and the ability to overcome such task. Ugwoke et al. (2017) defines stress as the product of ways a person responds and adjust to specific demands and threats they come across as they execute assigned tasks. Evans and Kelly (2004) believed that stress is a multifaceted and changing event between man and his environment. Stress may be positively or negatively perceived or experienced. Accordingly, the World Health Organization (2002) was of the view that positive perceived stress will spark positive side of people in their environment. Stress might be able to assist an individual to escape a dangerous situation. To this effect, D'Arcy (2007) noted that stress is a good thing, but the overload of it leads to negative results. Stress according to the American Psychological Association (APA) (2012) can be acute, episodic or chronic stress. Acute stress is the most common and it is short-term which arises from tasks of the past, present and future and does not have enough time to do the extensive damage associated with long-term stress (Hillman, 2015). According to Legg (2016), acute stress is healthy and not negative as it enables the individual's body and brain to be active in accommodating future stressful situations. Acute stress is better than episodic stress as it can only crop one's health but it is manageable, controllable and treatable. Episodic stress according to American Psychological Association (2012) is an acute stress extension which manifests from heavy burden with the signs of sleepless moment, uncommon body reaction to the environment, blood pressure, and pain of the chest among others. Legg (2016) asserted that episodic stress is dangerous because bad health effects are common in individuals living with it and it seems difficult for them to adopt healthy lifestyle.

Chronic stress seems to explain the ugly situation like broken families, poverty, bad career experience which result in depression. Hillman (2015) was of the view that it is unhealthy as affected person often grief for a long time; have high blood pressure and high heart rate. According to the American Psychological Association (2012), episodic stress emanates from trouble encounter and early childhood experience resulting from violence, rape and child abuse. Thawabieh and Qaisy (2012) opined that secondary school students' transition to tertiary education institutions (including Economics education students) could cause emotional, sociological and academic shock to students in their struggle to meet up with environmental and personal needs. Ibrahim, Mohtar, Sabo, Rahim and Ariffin (2015) noted that different environment in tertiary education institutions pose challenges to new intake as they are faced with new teaching and learning strategies, and academic task.

More so, stress whether acute, episodic or chronic can be destructive if not properly managed. Mate (2014) asserted that stress has a direct bearing on students' achievement or performance. According to Tooper (2007), the response to a specific stressful event by students can make the situation either positive or negative. Positive stress (eustress) is a feeling of happiness and excessive excitement. It is a form of stress that is not going to cause health issues but is actually good because it motivates students to revise and memorize what they learn as well as to work hard (Hillman, 2015). This form of stress is a feeling that enables students to adapt in a terrifying moment. Negative stress (distress) comes as a result of the feeling of anxiety, frustration or conflict.

In the assessment of students' perceived stress, there may or may not be gender differences. Cassell (2002) opined that gender is the social classification of having identifiable traits of either male or female. Gender is a broad analytical concept that spells the clarity of male and female functions (Okeke, 2004). The author also referred to gender as socially and culturally defined attributes and functions that differentiate male and female. The features and personality that are generally associated with being a male is known as masculine and while that of the female is feminine. Several studies vary in their findings concerning gender. Some has reported that males are more abstract in reasoning, more assertive, and so on, whereas, females were found to have more anxiety and worry, but are more organized (Bielinski \& Davison, 2003). Therefore, gender could be perceived as those socio-cultural features that differentiate male from female as it could determine their stress perception.

University students irrespective of gender affiliation and educational programme may have different stress perception. Stress according to National Institute for Occupational Safety and Health (2014) is the negative emotional reactions and poor mental responses that result when requirements doesn't meet up with the individual's strength, finance, and need. Perceived stress refers to opinions of students about too many academic demands placed on them. Stress, as it affects students, is the pressing task beyond students' body carriage in form of psychological, socio-personal, educational and environmental tension arising from students' learning environment. Studies in tertiary education institutions in the South-East zone of Nigeria revealed the presence and sources of 
stress in students (e.g. Amadi, Obidoa, Ogbonnaya, \& Eseadi, 2019; Igbokwe et al., 2019; Nwefuru et al., 2018; Ugwoke et al., 2018). Observations from researchers indicate that the Economics Education students in South-East Nigeria display symptoms of stress but the extent to which male and female students are affected is still unknown. It is important to investigate the gender differences in perceived stress among Economics Education students. Hence, the general purpose of the study was to investigate gender differences in perceived stress among Economics Education students in universities in South-East Nigeria. Specifically, the study seeks to determine mean difference in perceived stress among male and female Economics Education students in universities in South-East Nigeria.

\subsection{Research Question}

The study formulated and tested one research question:

What is the mean difference in perceived stress among male and female Economics Education students in universities in South-East Nigeria?

\subsection{Hypothesis}

The hypothesis below was raised and tested at 0.05 probability level:

There is no significant mean difference in perceived stress among male and female Economics Education students in universities in South-East Nigeria.

\section{Research Method}

This is a cross-sectional research study. The study was carried out in South-East, Nigeria. The study population comprises all the Economics Education students in universities in South-East Nigeria. The convenience sample for the study comprised of 135 final year Economics Education undergraduate students. Data were obtained using the Perceived Stress Scale (PSS), developed by Cohen, Kamarck and Mermelstein (1983). Students' score on PSS can range from 0 to 40 with higher scores indicating higher perceived stress but in a specific manner, it will read 0-13 for low stress, 14-26 for moderate stress while 27-40 is high perceived stress. The data for this study was collected by four research assistants. Respondents gave verbal informed consent. The instrument was distributed to the respondents and retrieved immediately after completion to avoid loss of the instrument. Mean, standard deviation and t-test were used to analyze the data collected with the hypothesis tested at 0.05 probability level.

\section{Results}

\section{Research Question}

What is the mean difference in perceived stress among male and female Economics Education undergraduate students in universities in South-East Nigeria?

Table 1. Mean difference in perceived stress among male and female economics education students in South-East Universities

\begin{tabular}{llcc}
\hline Students' Gender & N & Mean & Std. Deviation \\
\hline Male & 65 & 27.40 & 6.74 \\
Female & 70 & 29.64 & 5.84 \\
\hline
\end{tabular}

In Table 1, the result revealed that male Economics Education undergraduate students had a perceived stress mean of 27.40 with a standard deviation of 6.74 while female Economics Education undergraduate students had a perceived stress mean of 29.64 with a standard deviation of 5.84. This implies the existence of high level of perceived stress among this category of undergraduate students.

\section{Hypothesis}

There is no significant mean difference in perceived stress among male and female Economics Education undergraduate students in universities in South-East Nigeria. 
Table 2. Independent samples test of significant mean difference in perceived stress among male and female economics education undergraduate students

\begin{tabular}{llllllll}
\hline Gender & $\mathbf{N}$ & $\mathbf{M} \pm \mathbf{S D}$ & $\mathbf{t}$ & $\mathbf{D f}$ & Sig. & Mean Difference & $\mathbf{9 5 \%}$ CI \\
\hline Male & 65 & $27.40 \pm 6.74$ & -2.071 & 133 & 0.05 & -2.24286 & $-4.385,-0.100$ \\
Female & 70 & $29.64 \pm 5.84$ & & & & & \\
\hline
\end{tabular}

$\mathrm{M} \pm \mathrm{SD}=$ Mean, Standard Deviation; $\mathrm{N}=$ Number of Respondents, $\mathrm{CI}=$ Confidence Interval.

In Table 2, the result indicated that there is no significant mean difference in perceived stress among male and female Economics Education undergraduate students, $\mathrm{t}(133)=-2.071, p=0.05,95 \% \mathrm{CI}=-4.385, .100$. Therefore, the null hypothesis was not rejected.

\section{Discussion}

The present study found that there is no significant mean difference in perceived stress among male and female Economics Education students in universities in South-East Nigeria. This means that academic stress encountered by these students is not dependent on gender identities and expressions. Daniel et al. (2018) reported that students experience perceived stress among themselves in their struggle to academically perform to expectation. Ugwoke, et al. (2019) reported that male and female shares relatively equal stress in their academic environment. Mofida, Mona and Elham (2011) also revealed no significant variation in male and female students' perceived stress. Abdulahi (1999) reported that female students were more stressed than males. Asani, Farouk and Gambo (2016) revealed that there was no significant gender difference on sources of stress. Atindanbila and Bayem (2011) reported that was no significant gender differences in perceived stress among undergraduate students. However, Aesha, Saad Abdullah, Assaf, and Khalid (2017) reported that female medical students were more significantly stressed than their male counterparts. Edward, Samuel, Michael and Xiaosong (2015) reported that female undergraduate students perceived stress more than male students. Shaban et al. (2012) found that there was a high level of stress among female nursing students than their male counterparts. Because Economics education students are experiencing perceived stress irrespective of their gender, they have to be availed with equal opportunity to gain from programmes on stress management strategies. Economics Education specialists are also urged to implement gender-inclusive teaching interventions to help Economics Education undergraduate students to manage perceived stress.

\section{Conclusion}

Based on the finding of this study, the researchers conclude that there is no significant mean difference in perceived stress among male and female Economics Education students in universities in South-East Nigeria. Economics Education specialists are urged to implement gender-inclusive teaching interventions to help Economics Education undergraduate students to manage perceived stress.

\section{Competing Interests Statement}

The authors declare that there are no competing or potential conflicts of interest.

\section{References}

Abdulahi, O. E. (1999). Influence of sex, level of study and religious belief on the perception of stress among Nigerian undergraduate students. Journal of School Health Education, 6(1\&2), 48-57.

Aesha, F. S., Siddique, S. A., Assaf, A. A., \& Khalid, H. M. (2017). Perceived stress in Saudi undergraduate medical students. Journal of Medical and Allied Sciences, 7(1), 41-47.https://doi.org/10.5455/jmas.252925

Amadi, I. M., Obidoa, M. A., Ogbonnaya, N. O., \& Eseadi, C. (2019). Sources of stress and stress management among student nurses in Anambra state of Nigeria. International Journal of Education and Learning, 8(2), $7-14$.

American Psychological Association (2012). Stress: The different kinds of stress. Retrieved from http://www.apa.org/helcenter/stress-kind.aspx.

Asani, M. O., Farouk, Z., \& Gambo, S. (2016). Prevalence of perceived stress among clinical students of Bayero University Medical School. Nigerian Journal of Basic and Clinical Sciences, 55-58. https://doi.org/10.4103/0331-8540.176209

Atindanbila, S., \& Bayem, E. (2011). The types and incidence of stressors among students in the University of Ghana-Legon- ugspace.ug.edu.gh 
Bielinski, T., \& Davidson, M. I. (2003). A sex difference by item difficulty interaction in multiple choice. Journal of Educational Measurement, 38(1), 51-77.https://doi.org/10.1111/j.1745-3984.2001.tb01116.x

Cassell, E. (2002). Gender: Sexuality. Chicago: the world book Inc.

Cohen, S., Kamarck, T., \& Mermelstein, R. (1983).A global measure of perceived stress. Journal of Health and Social Behavior, 24, 386-396. https://doi.org/10.2307/2136404

D'Arcy, L. (2007). Stress. Retrieved from http://www.kidshealth.org

Daniel, C. O., Ajayi, A. D., Ogunyewo, O. A., Ajio, D. K., Andy, E., Oyedele, E., ... Gusen, N. J. (2018). Perceived impact of academic stress on academic performance among undergraduate nursing students of university of Jos. New Nigerian Journal of Clinical Research, 7, 8-15.

Edward, A., Samuel, A., Michael, M. M., \& Xiaosong, G. (2015). The Experience of Stress among Nursing Students in Nursing Training Colleges in Tamale, Ghana. International Journal of Psychology and Behavioral Sciences, 5(2), 89-97.

Evans, W., \& Kelly, B. (2004). Pre-registration diploma student nurse stress and coping measures. Nurse Education Today, 24(6), 473-482. https://doi.org/10.1016/j.nedt.2004.05.004

Finkelstein, N. D. (2011). Effects of problem-based Economics on high school Economics instruction. Retrieved from: http://www.sree.org/conferences/2018/program/downloads/slides/198.pdf.

Hall, S. (2013). Definition \& Importance of Economics. Retrieved from: http://www.ehow.com/about_6695532_definition-importance-Economics.html

Hillman, K. (2015). An introduction to the different types of stress. Retrieved from $\mathrm{http} / / / \mathrm{www}$. sgtresstips.com/an-introduction-to-thedifferent-types-of-stress

Ibrahim, Y. S., Mohtar, S. B., Sabo, M. A., Rahim, M. K. I. A., \& Ariffin, A. S. (2015). Stress and academic programme type: perspective on polytechnic students in Nigeria. American Journal of Public Health Research, 3(6), 214-220.

Igbokwe, U. L., Onyechi, K. C. N., Ogbonna, C. S., Eseadi, C., Onwuegbuchulam, A. C., Nwajiuba, C. A., ..., \& Anyaegbunam, E. N. (2019). Rational emotive intervention for stress management among English education undergraduates: Implications for school curriculum innovation. Medicine, 98(40), e17452. https://doi.org/10.1097/MD.0000000000017452

Legg, T. J. (2016). What's your stress type? The headline editorial team.Retrieved from $\mathrm{http}: / /$ www.healthline.com/health/whats-your-stresstype\#Outlook5

Mate, S. G. (2014). Sources of stress and coping strategies adopted by academic senior members in The University of Cape Coast. International Journal of Research In Social Sciences, 4(2), 1-9.

Mofida Y. A., Mona, T. E., \& ElhamAbdelkader, F. A. (2011). Sources of Stress as Perceived by Nursing Students at King Saud University. Medical Journal Cairo University, 79(1), 541-553.

National Institute for Occupational Safety and Health. (2014). Stress at work. Atlanta, GA: Centre for Disease Control and Prevention.

Nwefuru, B. C., Otu, M. S., Eseadi, C., Usen, S. A., \& Otu, F. M. (2018). Stress, Depression, Burnout and Anxiety among Chemistry Education Students in Universities in South-East, Nigeria. Journal of Consultancy, Training and Services, 2(2), 46-54.

Okeke, E. C. (2004). Gender sensitivity in class interaction. European Journal of Education Studies, 3(20), 201.

Shaban, I., Khater, W., \& Akho-Zaheya, L. (2012). Undergraduate nursing students' stress sources and coping behaviors during their initial period of clinical training: a Jordanian perspective. Nurse Education in Practice, 12(4), 204-209. https://doi.org/10.1016/j.nepr.2012.01.005

Thawabieh, A., \& Qaisy, L. (2012). Assessing stress among university students. International Journal of Contemporary Research, 2(2), 110-16.

Topper, E. F. (2007). Stress in the library workplace (pp. 561-564.). New Library World 11/12. https://doi.org/10.1108/03074800710838290

Ugwoke, S. C., Chijioke, E. G., Abella, E., Agundu, U., Oboegbulem, A. I., Oko, A. O., ..., \& Nwobi, U. A. (2018). Sources of Stress among Nursing Students in South-East Nigeria. International Journal of Applied Engineering Research, 13(17), 13212-13218. 
Ugwoke, S. C., Eseadi, C., Igbokwe, C. C., Chiaha, G., Nwaubani, O. O., Orji, C. T., ... \& Abugu, L. I. (2017). Effects of a rational-emotive health education intervention on stress management and irrational beliefs among technical college teachers in Southeast Nigeria. Medicine, 96(31), e7658. https://doi.org/10.1097/MD.0000000000007658

Yusuf, A. (2012). Economics Education. Retrieved from http://www.musero.org.ng/publications/ECONOMICSEDUCATION.pdf

\section{Copyrights}

Copyright for this article is retained by the author(s), with first publication rights granted to the journal.

This is an open-access article distributed under the terms and conditions of the Creative Commons Attribution license (http://creativecommons.org/licenses/by/4.0/). 